\title{
OBITUARY
}

\section{Jean-CharLes Doucet}

(1902-1954)

Doctor Jean-Charles Doucet, whose premature death occurred suddenly on May 1, 1954, at his home in Montreal, had been a devoted associate in the Department of Anaesthesia at Notre Dame Hospital during the past quartercentury.

After brilliant studies at Valleyfield College, where he obtaineld a B. L. degree, he entered Medicine at the University of Montreal, graduating with honours in 1929.

His innate godliness and meekness always concealed a deep-rooted desire for lofty achievements and an unswerving devotion to duty.

In 1930, Doctor Doucet went to Toledo, Ohio, to study under Dr. McKesson. Following his return to Montreal, he spent more time under the tutelage of Drs. Bourne and Griffith, acquiring scientific background and confidence which were to put within reach a cherished ambition: to help his fellow-men, and this in the new specialty of anaesthesia.

At that time, Notre Dame Hospital was in quest of industrious, enthusiastic and promising young doctors. Jean-Charles Doucet was selected to be amongst those. To the Department of Anaesthesia he gave his very best, a dedication without stint. 'Subsequently, he became Assistant Professor of Anaesthesiology at the University of Montreal and was made a Fellow of the International College of Anaesthetists in 1937.

An extremely unfortunate accident in his youth had added to his gentle character a certain timidity, made all the more attractive by the affection which he displayed towards patients, colleagues and all those who enjoyed the pleasure of his association and friendship.

The Canadian Anaesthetists' Society, Notre Dame Hospital and all his comrades in Anaesthesia are losing a loyal, sincere friend and a personality who has left his mark in the organization bf the specialty of Anaesthesia in Montreal. Thanks to his considerate help and advice, many stumbling-blocks were avoided; his gentle and calm mediation quietly found a solution to several difficult problems facing the profession.

Jean-Charles Doucet served the cause and the progress of Anaesthesia in Montreal with genuine distinction. His colleagues will be deeply affected by his loss and will miss the perfect gentleman and devoted collaborator he always was to all who had the privilege and pleasure of knowing him.

CONFRÈRE 